\title{
シスプラチン化学療法における吃逆の危険因子に関する検討
}

\author{
林＼cjkstart誠 ${ }^{1}$, 杉村勇人 ${ }^{1}$, 菅 幸生 $^{2}$, 河原昌美 ${ }^{2}$, 相宮光二 ${ }^{1}$, 宮本謙一 ${ }^{2}$ \\ 国立病院機構金沢医療センター薬斉科 \\ 金沢大学医学部附属病院薬斉部 2
}

\section{Study on Risk Factors for Hiccups Induced by Cisplatin-based Chemotherapy}

\author{
Makoto Hayashi ${ }^{* 1}$, Hayato Sugimura ${ }^{1}$, Yukio Suga², Masami Kawahara², \\ Kouji Aimiya ${ }^{1}$ and Ken-ichi Miyamoto ${ }^{2}$ \\ Department of Pharmacy National hospital Organization Kanazawa medical center ${ }^{1}$ \\ Department of Pharmacy Kanazawa University Hospital ${ }^{2}$ \\ $\left[\begin{array}{l}\text { Received A pril 24, } 2008 \\ \text { Accepted October } 29,2008\end{array}\right]$
}

Hiccups often occur in patients receiving cisplatin (CDDP)-based chemotherapy. In the present study, we investigated the incidence of hiccups in 162 patients who received CDDP as well as risk factors for developing hiccups.

Hiccups occurred in $40(25 \%)$ of the 162 patients, and 93\% were men. Twenty-six of the patients had hiccups within 48 hr of CDDP, and in 31 of them the hiccups continued for between 1 and 4 days. Twenty-eight of the patients received medication (shitei-decoction, chlorpromazine, metoclopramide, etc.) to relieve hiccups, which was effective in $30 \%$ of them. Hiccups developed in patients with osteochondro sarcoma (56\%), lung cancer (49\%), pancreatic cancer (40\%) and esopha gus cancer (23\%) receiving the following 4 chemotherapy regimens: CDDP + ADM + CAF (56\%), CDDP + DTX (50\%), CDDP + 5 FU (40\%), and CDDP + TS $1(20 \%)$ respectively.

The CDDP dosage $\left(\mathrm{mg} / \mathrm{m}^{2}\right)$ was higher in patients who had hiccups than in those who had none (80 \pm 22 vs $45 \pm 33$, $\mathrm{p}<$ $0.0001)$ and there was a positive correlation was between CDDP dosage and incidence of hiccups $(p<0.001)$, though all patients developing them received corticosteroids and $5 \mathrm{HT}_{3}$ antagonists.

Multiple logistic regression analysis showed that there were significant differences for the male sex (odds ratio $(O R)=8$, $95 \% \mathrm{Cl}=1.5-45.6)$, CDDP dose $(1.03,1.01-1.06)$, dexamethasone ( $\geqq 16 \mathrm{mg})(19.4,3.9-95.2)$ and granisetron $(6 \mathrm{mg})(20.9$, 3-143). We therefore concluded that the independent risk factors influencing the development of hiccups were the male sex and a high dose of CDDP in combination with dexamethasone ( $\geqq 16 \mathrm{mg})$, and granisetron $(6 \mathrm{mg})$.

Key words — cisplatin, hiccups, high dosage, corticosteroid, sex, $5 \mathrm{HT}_{3}$ antagonist

\begin{abstract}
緒言
シスプラチン(以下, CDDP と略す)を含むがん化学療 法施行患者への服薬指導を行っていると, 吃逆の副作用 を経験することがある . 症状は患者ごとに差があるもの の，夜間の睡眠が障害されるほど重症な場合もある.吃 逆は生命の危険に著しく影響するものではないが , 化学 療施行中の患者においては QOL を低下させる . 肺がん 化学療法に伴う吃逆の副作用に関する報告 ${ }^{12}$ によると CDDP を含む化学療法では高頻度に吃逆が発現するとさ れている．また，CDDPにより発現した吃逆は，性別と ステロイド投与か関係しているとの報告 ${ }^{34}$ がある．しか しながら，これらの報告では，CDDPの投与量や危険因 子に関する詳細な検討は行われていない. がん化学療法
\end{abstract}

による吃逆の発現機序は吃逆中枢の刺激よるものという 説5,6) もあるが，十分には解明されていない，CDDP を含 む化学療法は多くのがん患者に施行されており，吃逆の 危険因子を明確にすることはがん患者の QOL 改善につ ながると考えられる．兰こで本研究ではCDDPを含む 化学療法による吃逆の発現頻度，危険因子および炎の対 処方法について検討した .

本研究は国立病院機構金沢医療センターおよび金沢大 学医学部附属病院での倫理審査委員会の承認を得て行っ た研究である.

$$
\text { 方法 }
$$

\section{1. 調査対象}

2007 年 4 月から 9 月までの期間に国立病院機構金沢 
医療センターおよび金沢大学医学部附属病院において CDDPが施行されたがん患者を対象とした .

\section{2. 調査方法}

診療記録より対象患者の性別, 年齢, CDDP 投与量, 併用薬斉, 吃逆発現の有無, 吃逆発現時期, 持続期間, 発現コースについて retrospective に調査した .さらに吃 逆を National Cancer Institute Common Terminology Crite ria for A dverse Event ver 3.0(以下，CTCAE と略す)に従っ てグレード分類した .

\section{3. 吃逆の危険因子の検討}

対象患者を吃逆の有無で分類し，2群間で各因子を単 変量解析にて比較した。

吃逆発現の有無を従属変数, 単変量解析で有意な差を 認めた因子を説明変数として多変量解析を行い, 吃逆の 危険因子について検討した .

\section{4. 吃逆に対する薬物療法の調査}

吃逆の治療に使用された薬剂をカルテより調査し, カ ルテ記載から吃逆に対する効果を判定した .

\section{5. 抗がん斉の略語}

今回の調査で用いた抗がん斉は, 抗がん斉適正使用の ガイドラインで使用されている用語の定義と略語に準じ て,以下のように略した .

イリノテカン：CPT 11, エトポシド : VP 16, エピル ビシン : EPI , ゲムシタビン: GEM , シタラビン : $\mathrm{AraC}$, ダカルバジン : DTIC, ドキソルビシン : ADM , ドセタキセル：DTX，ニムスチン：ACNU，ビノレルビ ン: VNR, ビンデシン: VDS, フルオロウラシル : 5 $\mathrm{FU}$ ，ミトキサントロン：MIT , メトトレキサート：MTX

\section{6. 統計解析}

データ解析は Statistics Program for Social Science for Windows(ver 11)を使用した．2 群間の検定には Fischer の直接確率法，t-検定を使用し，5\%の危険率をもって 有意な差とした .がん種別，レジメン別の吃逆発現につ いてはオッズ比, 95\% 信頼区間を単変量解析で算出し た．吃逆の独立した危険因子の検討は, ロジスティック 回帰分析を用い, 調整オッズ比，95\% 信頼区間を算出 した .

\section{結果}

\section{1. 吃逆発現と患者背景}

調査期間中 CDDP が投与されていた患者は 162 例で あり，弚のうち 40 例(25\%)の患者に吃逆が発現してい た.この40例(吃逆発現群)を，吃逆を起こしていない 患者 122 例(吃逆非発現群)と比較した(Table 1) . 性別の
比較では, 男性のほうがより多く吃逆を発現していた (男vs女 : $30 \%$ vs $8 \%, p<0.01$ ). 年齢は吃逆発現群 53 \pm 14 (平均 \pm 標準偏差)歳, 吃逆非発現群 62+ 15歳と吃 逆発現群のほうが低い値を示した $(\mathrm{p}<0.005) . C D D P の$ 投与量 $\left(\mathrm{mg} / \mathrm{m}^{2}\right)$ は吃逆発現群のほうが明らかに大きい值

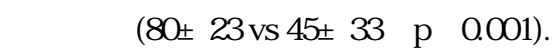

\section{2. 吃逆発現時期，持続期間とグレード分類}

吃逆を発現した 40 例中 36 例が CDDP 投与後 2 日以 内に吃逆を起こしていた(Table 2). 吃逆の持続期間は 1 日間が 21 例と最も多く，次いで 2 日間が 10 例，3日間 が7例であった．吃逆発現コースは，1コースのみが 22

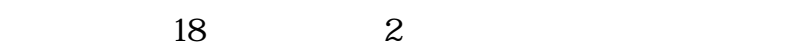
た. 5 コース化学療法中にいずれの場合も吃逆が発現し た症例も認められた。CTCAEのグレード分類では，グ レード 1 が 12 例 , グレード 2 が 18 例, グレード 3 が 10 例であった 。

3. がん種，レジメン別吃逆発現頻度

がん種別吃逆発現頻度とオッズ比を Table 3 に示し

Table 1 . Correlation between onset of hiccups pa tient characteristics

\begin{tabular}{|c|c|c|c|c|c|c|}
\hline \multirow[b]{3}{*}{ variable } & \multirow{3}{*}{$\begin{array}{c}\text { Total } \\
\text { No.of } \\
\text { Patients }\end{array}$} & \multicolumn{4}{|c|}{ Hiccups } & \multirow[b]{3}{*}{ P } \\
\hline & & \multicolumn{2}{|c|}{ Yes } & \multicolumn{2}{|c|}{ No } & \\
\hline & & $\begin{array}{c}\text { No.of } \\
\text { Patients }\end{array}$ & $\%$ & $\begin{array}{c}\text { No.of } \\
\text { Patients }\end{array}$ & $\%$ & \\
\hline Total & 162 & 40 & 25 & 122 & 75 & \\
\hline Sex & & & & & & $0.009^{*}$ \\
\hline Male & 123 & 37 & 30 & 86 & 70 & \\
\hline Female & 39 & 3 & 8 & 36 & 92 & \\
\hline \multicolumn{7}{|l|}{ Age (y) } \\
\hline $8-49$ & 26 & 9 & 35 & 17 & 65 & \\
\hline $50-64$ & 60 & 23 & 38 & 37 & 62 & \\
\hline $65-83$ & 76 & 8 & 11 & 68 & 89 & \\
\hline mean $\pm S D$ & $60 \pm 15$ & $53 \pm 14$ & & $62 \pm 15$ & & 0.002 \\
\hline $\begin{array}{l}\text { CDDP dose } \\
\left(\mathrm{mg} / \mathrm{m}^{2}\right)\end{array}$ & $53 \pm 34$ & $80 \pm 22$ & & $45 \pm 33$ & & $<0.001^{* 2}$ \\
\hline
\end{tabular}

$※ 1$ : Fischer's test, $※ 2$ : t-test

Table 2 . Onset and duration of hiccups and $\mathrm{NCl}$ CTCAE

\begin{tabular}{cccccc}
\hline \multicolumn{2}{l}{ Onset of hiccups $(\mathrm{n}=40)$} \\
\hline Day 1 & Day2 & Day3 & Day4 & $\cdots$ & Day 8 \\
\hline 12 & 24 & 2 & 1 & & 1
\end{tabular}

Duration of hiccups $(n=40)$

\begin{tabular}{cccc}
\hline 1 day & 2 days & 3 days & 4days \\
\hline 21 & 10 & 7 & 2
\end{tabular}

Course of hiccups $(n=40)$

\begin{tabular}{ccccc}
\hline 1 course & $1-2$ course & $1-3$ course & $1-4$ course & $1-5$ course \\
\hline 22 & 12 & 2 & 2 & 2 \\
\hline NCI CTCAE $(n=40)$ & & & \\
\cline { 1 - 2 } Grade1 & Grade2 & Grade3 & & \\
\cline { 1 - 3 } 12 & 18 & 10 & & \\
\hline
\end{tabular}


た.肺がん, 骨・軟部腫瘍に吃逆発現数が多く, 次いで 肝臓がん，食道がんであった. 15 がん種中 7 がん種に 吃逆が認められた . 単変量解析でのオッズ比は肺がん， 骨軟部腫瘍において他のがん種に比較し有意に大きい値 を示し $(p<0.05) ，$ 胃がんでは有意に小さい值を示した $(p$ $<0.05)$.

レジメン別吃逆発現頻度とオッズ比を Table 4 に示し た.21レジメン中 15レジメンに吃逆が認められた . 単 変量解析でのオッズ比は CDDP + DTX と CDDP + ADM + caffeineが他のレジメンに比較し有意に大きい值を示 した $(p<0.05)$.
4. ステロイド, $5 \mathrm{HT}_{3}$ 受容体拮抗薬併用による吃逆発 現への影響

ステロイドは 162 例中 134 例に併用されており，光の うち 40 例(30\%)か吃逆を発現していた(Table 5) . 吃逆の 発現はデキサメタゾン 31 例(28\%), デキサメタゾン， メチルプレドニゾロン 9 例(50\%)であった . デキサメタ ゾンを投与された 108 例のうち , $16 \mathrm{mg}$ 以上投与された 患者では 37 例中 23 例(62\%)に吃逆が発現していたのに 対し, $16 \mathrm{mg}$ よ少ない投与量では 89 例人中 17 例(19 \%)に発現していた . 吃逆が発現した 40 例では全例ステ ロイドを併用していた .

$5 \mathrm{HT}_{3}$ 受容体捛抗薬は 162 例中 152 例に併用されてお

Table 3 . Classification of cancer and occurrence of hiccups

\begin{tabular}{l|c|c|c|c|c|c}
\hline & $\begin{array}{c}\text { No of } \\
\text { Patients }\end{array}$ & $\begin{array}{c}\text { Occurrence } \\
\text { of hiccups }\end{array}$ & $\begin{array}{c}\text { Frequency } \\
(\%)\end{array}$ & $\begin{array}{c}\text { Odds } \\
\text { Ratio }\end{array}$ & $95 \% \mathrm{CI}$ & $\mathrm{p}$ \\
\hline lung cancer & 39 & 19 & 49 & 2.9 & $1.73-4.86$ & $<0.05$ \\
\hline gastric cancer & 26 & 1 & 4 & 0.1 & $0.02-0.87$ & $<0.05$ \\
\hline liver cancer & 25 & 4 & 16 & 0.6 & $0.21-1.59$ & N.S. \\
\hline osteochondro sarcoma & 16 & 9 & 56 & 3.9 & $1.56-9.85$ & $<0.05$ \\
\hline esophageal cancer & 13 & 3 & 23 & 0.9 & $0.26-3.16$ & N.S. \\
\hline head and neck cancer & 13 & 2 & 15 & 0.6 & $0.13-2.40$ & N.S. \\
\hline pancreatic cancer & 5 & 2 & 40 & 2.0 & $0.35-11.7$ & N.S. \\
\hline uterine cancer & 8 & 0 & 0 & - & - & - \\
\hline colon cancer & 5 & 0 & 0 & - & - & - \\
\hline melanoma & 4 & 0 & 0 & - & - & - \\
\hline ovarian cancer & 3 & 0 & 0 & - & - & - \\
\hline gallbladder cancer & 2 & 0 & 0 & - & - & - \\
\hline others & 3 & 0 & 0 & - & - & - \\
\hline
\end{tabular}

Others : follicular lymphoma, bladder concer, testicular cancer CI : Confidence interval

Table 4 . Chemotherapy and occurrence of hiccups

\begin{tabular}{l|c|c|c|c|c|c}
\hline Regimen & $\begin{array}{c}\text { No of } \\
\text { Patients }\end{array}$ & $\begin{array}{c}\text { Occurrence of } \\
\text { hiccups }\end{array}$ & $\begin{array}{c}\text { Frequency } \\
(\%)\end{array}$ & $\begin{array}{c}\text { Odds } \\
\text { Ratio }\end{array}$ & $95 \% \mathrm{CI}$ & $\mathrm{P}$ \\
\hline CDDP+DTX & 22 & 11 & 50 & 3.1 & $1.43-6.49$ & $<0.05$ \\
\hline CDDP+ADM+caffeine & 16 & 9 & 56 & 3.9 & $1.56-9.85$ & $<0.05$ \\
\hline CDDP+CPT11 & 21 & 2 & 10 & 0.3 & $0.08-1.32$ & N.S. \\
\hline CDDP+TS1 & 20 & 4 & 20 & 0.8 & $0.27-2.15$ & N.S. \\
\hline CDDP+5FU+INF $\alpha$ & 14 & 1 & 7 & 0.2 & $0.03-1.74$ & N.S. \\
\hline CDDP artery injection & 11 & 1 & 9 & 0.3 & $0.04-2.31$ & N.S. \\
\hline CDDP+VP16 & 9 & 2 & 22 & 0.87 & $0.19-4.03$ & N.S. \\
\hline CDDP monotherapy & 8 & 1 & 13 & 0.4 & $0.06-3.43$ & N.S. \\
\hline CDDP+5FU & 5 & 2 & 40 & 2.0 & $0.35-11.7$ & N.S. \\
\hline CDDP+GEM & 5 & 1 & 20 & 0.8 & $0.09-6.63$ & N.S. \\
\hline CDDP+VNR & 3 & 2 & 67 & 6.1 & $0.57-65.5$ & N.S. \\
\hline CDDP+5FU+MIT & 2 & 1 & 50 & 3.1 & $0.20-47.7$ & N.S. \\
\hline CDDP+5FU+DTX & 1 & 1 & 100 & - & - & - \\
\hline CDDP+5FU+MTX+INF $\alpha$ & 1 & 1 & 100 & - & - & - \\
\hline CDDP+5FU+MTX & 1 & 1 & 100 & - & - & - \\
\hline
\end{tabular}

Other regimens (non occurrence of hiccpus)

CDDP+ EPI+ PAC, CDDP+ VP 16+ EPI, CDDP+ 5 FU+ GEM

CDDP+ ADM+ VDS+ MTX, CDDP+ DTIC+ ACNU+ TAM, CDDP+ VP 16+ AraC+ Rituximab 
Table 5 . Influence of hiccups by Combination with Corticosteroid and 5- $\mathrm{HT}_{3}$ antagonist

\begin{tabular}{|c|c|c|c|c|}
\hline & $\begin{array}{c}\text { No.of } \\
\text { Patients }\end{array}$ & $\begin{array}{c}\text { Hiccups } \\
(+)\end{array}$ & $\begin{array}{c}\text { Hiccups } \\
(-)\end{array}$ & $\begin{array}{c}\text { Incidence of hiccups } \\
(\%)\end{array}$ \\
\hline Stero $(-)$ & 28 & 0 & 28 & 0 \\
\hline Stero $(+)$ & 134 & 40 & 94 & 30 \\
\hline Dexamethasone & 108 & 31 & 77 & 28 \\
\hline Hydrocortisone & 7 & 0 & 7 & 0 \\
\hline Methylprednisolone & 1 & 0 & 1 & 0 \\
\hline Dexamethasone+Methylprednisolone & 18 & 9 & 9 & 50 \\
\hline $5 \mathrm{HT}(-)$ & 10 & 0 & 10 & 0 \\
\hline $5 \mathrm{HT}(+)$ & 152 & 40 & 112 & 29 \\
\hline Granisetron & 100 & 31 & 69 & 31 \\
\hline Ramosetron & 34 & 3 & 31 & 9 \\
\hline Azasetoron & 10 & 5 & 5 & 50 \\
\hline Ondansetron & 8 & 1 & 7 & 13 \\
\hline Stero $(-) / 5 \mathrm{HT}(-)$ & 4 & 0 & 4 & 0 \\
\hline Stero $(+) / 5 \mathrm{HT}(-)$ & 6 & 0 & 6 & 0 \\
\hline Stero $(-) / 5 \mathrm{HT}(+)$ & 24 & 0 & 24 & 0 \\
\hline Stero $(+) / 5 \mathrm{HT}(+)$ & 128 & 40 & 88 & 31 \\
\hline
\end{tabular}

Stero: corticosteroid, $5 \mathrm{HT}: 5 \mathrm{HT}_{3}$ antagonist

り，弚のうち 40 例(29\%)に吃逆が発現していた．吃逆 の発現はグラニセトロン 31 例(31\%), ラモセトロン 3 例(9\%)，アザセトロン 5 例(50\%)，オンダンセトロン 1 例(13\%)であった .グラニセトロンを投与された 100 例 のうち，3 mg 1 回投与された群では 84 例中 16 例(20\%) に吃逆が発現したのに対し，3mgを2回投与された群 では18例中 15例(83\%)に発現していた.吃逆が発現し た 40 例では全例 $5 \mathrm{HT}_{3}$ 受容体拮抗薬が併用されてい た。

吃逆が発現した 40 例では全例で, ステロイドと $5 \mathrm{HT}_{3}$ 受容体拮抗薬が併用されていた。

\section{CDDP 投与量と吃逆発現}

CDDP 投与量と吃逆発現との関係を Fig. 1 に示した . 吃逆は CDDP 投与量が $20 \mathrm{mg} / \mathrm{m}^{2}$ から $125 \mathrm{mg} / \mathrm{m}^{2}$ の間で 発現していた . $20 \mathrm{mg} / \mathrm{m}^{2}$ 未満の投与量では吃逆は認め られなかったのに対し，70 $\mathrm{mg} / \mathrm{m}^{2}$ 以上においては高頻 度に吃逆がみられた.CDDPの投与量と吃逆発現率(発 現率 $=$ 吃逆発現患者 $/ C D D P$ 投与患者 $\times 100)$ との間に は，有意な正の相関か認められた( $<<0.05$, Fig. 2).

\section{6. 吃逆発現に対する危険因子}

単変量解析の結果吃逆発現に影響が認められた因子 と, 吃逆発現群に併用していない症例がなかったため, 単変量解析のできなかったステロイド併用, $5 \mathrm{HT}_{3}$ 受容

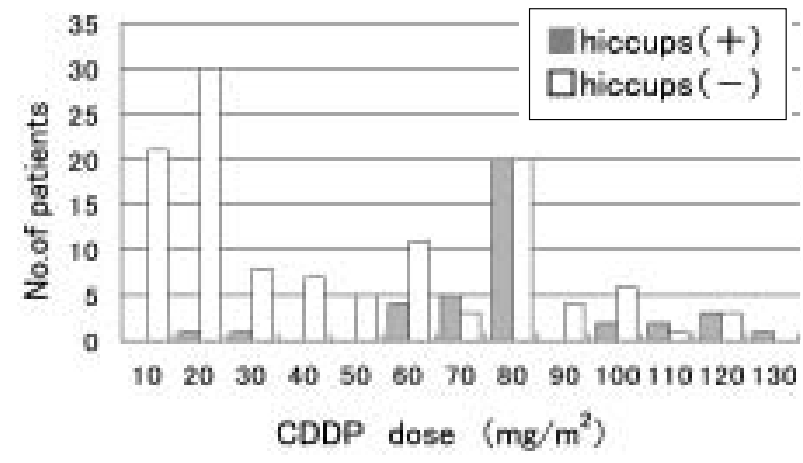

Fig. 1 . Incidence of hiccups by CDDP dose

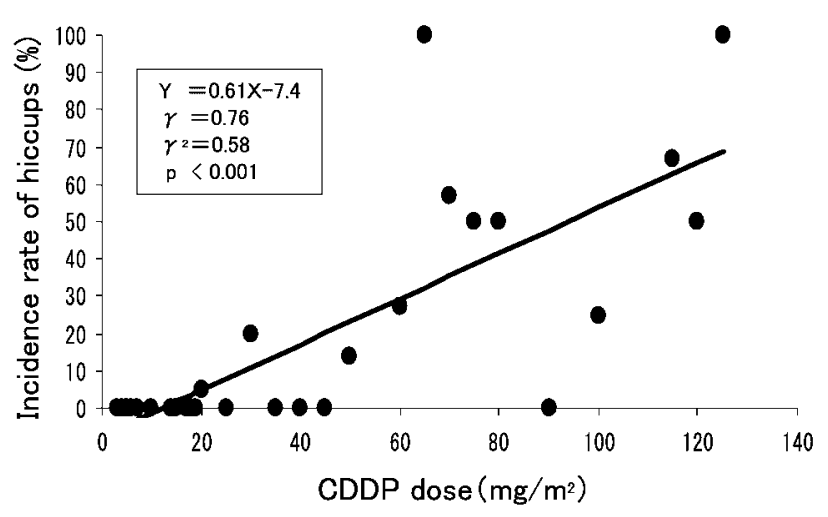

Fig. 2 . Correlation between hiccups and CDDP dose 
体拮抗薬併用を多変量解析した結果, 性別(男性), CDDP 投与量 , デキサメタゾン $16 \mathrm{mg}$ 以上併用 , グラニ セトロン $6 \mathrm{mg} /$ day 併用の4項目において有意な差を認 めた(Fig. 3).

\section{7. 吃逆の薬物療法}

吃逆の薬物治療が行われた 28 例に使用された薬剂 は, 使用頻度順に柿のへた水 9 例 , クロルプロマジン内 服 5 例，メトクラミド注射 4例であった . 兴の他バクロ フェン内服, クロナゼパム内服 , クロルプロマジン注 射，ジアゼパム注射が使用されていた．1種類では効果 がなく，2種類以上の薬阂を使用した症例が 7 例あっ た、薬物療法により吃逆が完全に治まったのは 28 例中 10 例であり，8例は薬を使用したときは治まるがまた出 る，7例は薬を使用してもまったく変化がなかった．柿 のへた水，クロルプロマジン内服・注射，およびメトク ロプラミド注射は吃逆に対して著効を示した症例が認め られた。

\section{考察}

今回の調査では CDDP が投与された 162 人中 40 人(25 \%)に吃逆が発現していた . 抗がん剂承認時のデータを まとめた報告6)では，CDDP の吃逆発現率は $0.43 \%$ とさ れている.他の 9 種類の抗がん斉の発現率は合計で 0.39 \%であり, 承認時のデータにおいても，CDDPは他の抗 がん剂に比較して吃逆の頻度が高い薬剂であることがわ かる．しかしながら，これらのデータは単剂のものであ り，今回の結果とは隔たりがある．CDDP投与中に吃逆 が発現した報告によるとバラツキはあるものの，少数の 検討まで含めると発現率は 1.4-89\% である ${ }^{7-15)}$. これら
の報告と比較すると今回の結果は大きく離れたデータで はない.CDDP 投与中の吃逆は希な副作用ではないが確 認された .

CDDP 投与中の吃逆は女性に比較し男性のほうが明ら かに高い発現率であった . 肺がんでの 2 報 ${ }^{12)}$ の報告では 吃逆が発現した 37 例と 11 例の全例が男性であつた . ま た，他の報告)でも有意に男性が多く発現していること を示している. 今回のわれわれの結果もこれらの報告と 同樣であり，男性は吃逆発現に対してより注意が必要で あることが改めて示された . 年齢に関しては今回の検討 で若年の患者に多く認められたが，独立した危険因子と しては示されなかった . Liaw らは年齢と吃逆との関係

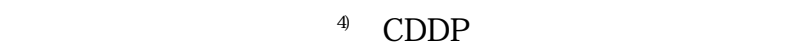
関係なく発現することが示された .

がん種別吃逆発現頻度の検討では肺がん，骨・軟部腫 瘍において高頻度に吃逆が発現する傾向がみられた．し かし，これらの要因は多変量解析では有意な差を示さな かったことから，独立した危険因子としては否定され た . 胃がんにおいては単変量解析で低い発現率であった が，独立した因子ではなかった．今回の調査では光の他 に肝がん, 食道がん, 脺がん, 頭頸部がんも含め 7 がん 種に吃逆は認められた . 婦人科がん泟尿器科がん年悪 性黑色腫 ${ }^{14)}$ と今回認められなかったがん種においても CDDP 投与中の吃逆は報告されており，CDDP が投与さ れているいずれのがん種においても吃逆発現の可能性が あることが示唆された .レジメン別の検討においても同 樣に多変量解析で有意な差が認められたレジメンはな

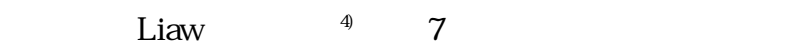
たと報告しているが , レジメンごとの頻度については検 討されていない . CDDP を含めたレジメンにおいては特 に吃逆発現の危険因子となるレジメンはなく，いずれの

\begin{tabular}{llll}
\hline \multicolumn{1}{c}{ Risk Factor } & AOR & $95 \% \mathrm{CI}$ & $\mathrm{P}$ \\
\hline age & 0.97 & $(0.92-1.02)$ & 0.26 \\
sex & 8.18 & $(1.5-45.6)$ & 0.02 \\
lung cancer & 0.37 & $(0.06-2.2)$ & 0.28 \\
gastric cancer & 1.02 & $(0.09-11.0)$ & 0.99 \\
CDDP+DTX & 3.15 & $(0.63-15.8)$ & 0.16 \\
CDDP+ADM+CAF & 0.84 & $(0.07-10.5)$ & 0.89 \\
GDDP dose & 1.03 & $(1.01-1.06)$ & 0.04 \\
cortico steroid & 863.6 & $\left(0-8 * 10^{26}\right)$ & 0.81 \\
dexamethasone $(\geqq 16 \mathrm{mg})$ & 19.4 & $(3.9-95.2)$ & $<0.001$ \\
5HT ${ }_{3}$ antagonist & 7974 & $\left(0-1 * 10^{40}\right)$ & 0.83 \\
granisetron(6mg/day) & 20.9 & $(3-143)$ & 0.002 \\
\hline
\end{tabular}

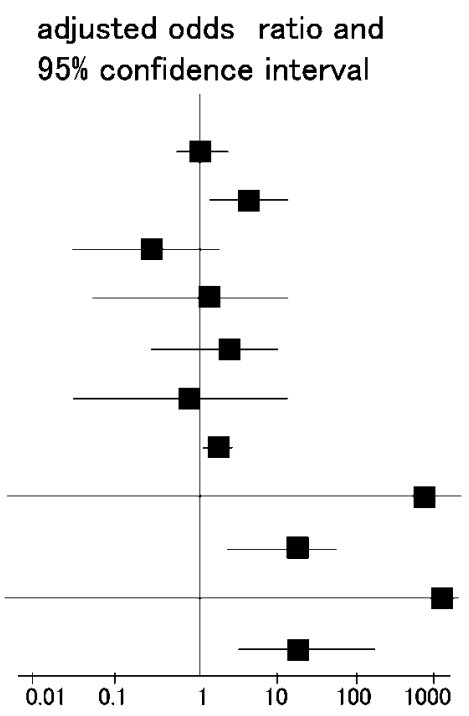

Fig. 3 . Risk Factor of hiccups, adjusted odds ratio by multiple logistic regression ※ OR : adjusted odds ratio , $\mathrm{Cl}$ : Confidence interval 
レジメンにおいても吃逆発現の可能性があることが示唆 された . また , CDDP投与時間と吃逆の関係に関して は，今回すへてて症例において確認はできなかったが， レジメンの用法を遵守していることを考えると投与時間 はレジメンごとに統一されており，投与時間は吃逆の発 現には影響を及ぼしていないことが推察された .

CDDP は単独で投与されることはほとんどなく，支持 療法も含めると数種類の薬剂が CDDP と同日に投与さ れることとなり，これらの併用薬斉の吃逆に及ぼす影響 を検討することは重要である．他の報告においても制吐 剂としてのステロイドと $5 \mathrm{HT}_{3}$ 受容体拮抗薬はほぼ全例 で使用されている ${ }^{3-14)}$ ，光こでステロイド， $5 \mathrm{HT}_{3}$ 受容 体拮抗薬の併用と吃逆との関係を検討した . まずステロ イドは吃逆発現した全例に投与されていたが, デキサメ タゾンのみに限定すると，16 mg 以上投与された群で明 らかに多く発現していた。CDDP と高用量のデキサメタ ゾンを併用することは吃逆を発現する可能性が示唆され た .デキサメタゾンは, 単剂で吃逆の発現が報告されて いる ${ }^{16-18)}$. いずれもデキサメタゾンの投与中止により速 やかに吃逆が消失し再投与により吃逆が発現しているこ とから，デキサメタゾンが原因であると示唆されてい る.デキサメタゾンは血液 - 脳関門により脳への移行性 は悪いとされているが, 高用量では脳内に移行し, 視床 下部の海馬にあるステロイド受容体を活性化する ${ }^{199}$. こ れにより吃逆反射弓の遠心路を刺激するとされている． しかし弚の作用はデキサメタゾンのみでは弱い ${ }^{20}$. 一 方，CDDP は腸クロム親和性細胞を刺激し，セロトニン を放出し，遠心性の迷走神経を活性化する．これにより 吃逆中枢を刺激し，吃逆を誘発するのではないかと考え られている21) .よってデキサメタゾンと CDDP は相乗的 に働き，吃逆を起こすのではないかと考えられた。よっ て CDDP 投与時にデキサメタゾンの高用量を併用する ことは吃逆の危険因子になると考えられた . 一方 $5 \mathrm{HT}_{3}$ 受容体拮抗薬と吃逆発現に関しては, $5 \mathrm{HT}_{3}$ 受容体拮抗 薬が単独で投与されることはないため, 作用機序を論じ た報告はほとんどない．5HT3 受容体拮抗薬による吃逆 発現機序は以下のように推察される.CDDPによって腸 クロム親和性細胞から放出されたセロトニンが, $5 \mathrm{HT}_{3}$ 受容体を遮断されていることにより $5 \mathrm{HT}_{4}$ 受容体に集中 する.これにより腸管運動が光進され，腹部迷走神経を 介して吃逆中枢の刺激に達するのではないかと考えられ $3^{2211}$. 以上のことから CDDP投与時のステロイド， 5 $\mathrm{HT}_{3}$ 受容体拮抗薬の併用は吃逆発現を誘発すると考えら れた . 今回の結果より，特にデキサメタゾンの $16 \mathrm{mg}$ 以上の高用量併用とグラニセトロン $6 \mathrm{mg} / \mathrm{day}$ の併用が 吃逆発現に影響を及ぼしていることが明らかとなった .

CDDP の投与量と吃逆発現率には正の相関が認められ た. $70 \mathrm{mg} / \mathrm{m}^{2}$ 以上の投与患者においては発現率が大き く，調整オッズ比においても有意な差が認められてお

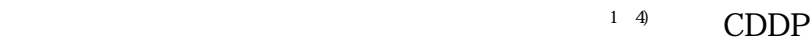

の投与量に関しては 50-100 mg/m² までの幅があり, 吃 逆発現との関係は十分に検討できておらず，今回の検討 でCDDP投与量と吃逆発現との用量依存的な関係は初 めて明らかとなった .

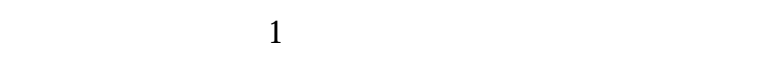
$55 \%$ であり，光の後投与継続したにもかかわらず，吃 逆が継続した患者は $45 \%$ であった .さらに投与を繰り 返すごとに出現する割合は減少したことから，CDDPの 反復投与による蓄積により吃逆が発現する可能性は否定 的であることが示唆された．今回吃逆を起こした 40 例 では，90\%の患者が48時間以内に発現し，また QOL に大きく影響を及ぼす夜間の睡眠を阻害するものが 30 \%認められたことから, 早期の対応が重要であることが わかった . 吃逆の薬物療法が施行された 28 人中 $65 \%$ は 薬物療法の効果を認めた . 柿のへた水, クロルプロマジ ンの内服・注射 , メトクロプラミドの内服は著効を示し た症例があった . 吃逆の薬物療法は他にメトクロプラミ ド , クロナゼパム , バクロフェンが有効であるという症 例報告がある ${ }^{12.5)}$ ．また，柿のへた水の吃逆に対する効 果を retrospectiveに調査した報告では22)，108人の吃逆 患者に対し $53 \%$ が完全寛解であり，弚のうちがん患者 においても，54\%が著効となっており，がん患者に対 する有効性が示されている．しかし，柿のへた水は薬斉 部で調製されており，一度調剤したものの返納は不可能 であるためあらかじめ準備しておくには不向きである . 以上のことから，CDDP の化学療法を予定されている患 者においては通常の服薬指導に加え，48時間以内に吃 逆の発現する可能性があることをあらかじめ説明し，兴 の対応としてクロルプロマジンやメトクロプラミドの内 服を準備し，夜間でも対応できるようにしておくことが 重要であると考えられた . 光れでも治まらなければ翌日 に柿のへた水を処方してもらうことも有効な方法であ る。

以上より，CDDPを含む化学療法を施行する患者にお いては, 男性, CDDP 投与量, デキサメタゾン $16 \mathrm{mg}$ 以 上の併用，グラニセトロン $6 \mathrm{mg} / \mathrm{day}$ の併用が吃逆の独 立した危険因子であることが明らかとなった . また 、こ れらの患者へはあらかじめ吃逆が発現する可能性がある ことを説明し，弚の対処方法を決めておくことが重要で あると考えられた 。

吃逆はQOL を大きく害する副作用であり，乥の危険 因子を明確にし，対処方法を確立することは薬凧師が患 者の薬物療法に貢献する重要な役割であると考える．

\section{引用文献}

1) K. Shibata, K. Kasahara, M. Fujimura, Hiccps observed during Chemotherapy for lung cancer, Jpn. J. Lung Cancer, 40, 33-37 (2000).

2) K. Teramoto, M. Kuwabara, Y. Matsubara, Hiccups induced 
by systemic chemo- therapy for lung cancer, Jpn. J. Lung Cancer, 41 , 191-194 (2001).

3) C.C. Liaw, C.H. Wang, H.K. Chang, H.M. Wang, J.S. Hung, Y.C. Lin, J.S. Chen, Cisplatin-Related Hiccups: Male Predominance, Induction by Dexamethasone, and Protection A gainst Nausea and Vomiting, J. Pain. Symptom. Manage., 30, 359-366 (2005).

4) C.C. Liaw, C.H. Wang, H.K. Chang, C.T. Liau, K.Y. Yeh, J.S. Hung, Y.C. Lin, Gender discrepancy observed between chemotherapy-induced emesis and hiccups, Support Care Cancer, 9 , 435-441 (2001).

5) J.H. Lewis, Hiccups: Causes and Cure, J. Clin. Gastroenterol., 7 , 539-552 (1985).

6) F. Eguchi, T. Taguchi, H. Furue, M. Ikeda, S. Tsukakoshi, Examination on efficacy and safety of concurrent use of ondansetron hydrochloride and steroid in gynecological cancer patients on cisplatin, Gan To Kagaku Ryoho, 10 ,1423-1429 (2001).

7) N. Horichi, T. Taguchi, H. Furue, M. Ikeda, S. Tsukakoshi, Examination on efficacy and safety of concurrent use of ondansetron hydrochloride and steroid in lung cancer patients on cisplatin, Gan To Kagaku Ryoho, 7 , 953-960 (2001).

8) N. Voravud, H. Suwanrusmee, Phase II trial of tropisetron and dexamethasone in the prevention of cisplatin-induced emesis, J. Med. Assoc. Thai., 83 , 668-675 (2000).

9) I. Sekine, Y. Nishiwaki, R. Kakinuma, K. Kubota, F. Hojo, T. Matsumoto, H. Ohmatsu, M. Yokozaki, T. Kodama, A randomized crossover trial of granisetron and dexametha sone versus granisetron alone: the role of dexamethasone on day 1 in the control of cisplatin-induced delayed emesis, Jpn. J. Clin. Oncol ., 26 , 164-168 (1996).

10) M.J. A hn, J.S. Lee, K.H. Lee, C. Suh, S.S. Choi, S.H. Kim, A randomized double blind trial of ondansetron alone versus in combination with dexamethasone versus in combina tion with dexamethasone and lorazepam in the prevention of emesis due to cisplatin- based chemotherapy, Am. J. Clin. Oncol ., 17 , 150-156 (1994).

11) L. Baltzer, M.G. Kris, L.B. Tyson, J.R. Rigas, K.M. Pisters, The addition of ondansetron to the combination of metoclopramide,dexamethasone,and lorazepam did not improve vomiting prevention in patients receiving high-dose cis platin, Cancer, 73 , 720-723 (1994)

12) T. Hashimura, K. Okumura, T. A kao, T. Nakagawa, Combination chemotherapy of methotrexate, etoposide, adriamycin and cisplatin (M-EAP) for advanced urothelial cancer, Hinyokika Kiyo, 37 , 685-688 (1991).

13) H. Saito, H. A mano, Y. Y asuda, H. Tsunekawa, K. Fujimoto, S. Yoshii, K. Shimokata, ntiemetic combination of metoclopramide and methylprednisolone for cisplatininduced vomiting, Gan To Kagaku Ryoho, 12 , 1980-1982 (1985).

14) D.J. Stewart, L.G. Feun, M. Maor, M. Leavens, M.A. Burgess, R.S. Benjamin, G.P. Bodey, Weekly Cisplatin during cranial irradiation for malignant melanoma metastatic to brain, J. Neurooncol ., 1 , 49-51 (1983).

15) Y. Takiguchi, R. Watanabe, K. Nagao, T. Kuriyama, Hiccups as an adverse reaction to cancer chemotherapy, J. Natl. Cancer. Inst., 94 , 1175-1176 (2002).

16) R.J. Cersosimo, M.T. Brophy, Hiccups with high dose dexamethasone administration : a case report, Cancer, 82 , 412414 (1998).

17) D.F. Thompson, J.P. Landry, Drug-induced hiccups, Ann. Pharmacother., 31 , 1264-1265 (1997).

18) J. Ross, M. Eledrisi, P. Casner, Persistent hiccups induced by dexamethasone, West. J. Med., 170, 51-52 (1999).

19) E.R. De Kloet, E. V reugdenhil, M.S. Oitzl, M. Joels, Brain corticosteroid receptor balance in health and disease Endocr. Rev., 19 , 269-301 (1998).

20) A.H. Miller, R.L. Spencer, M. Pulera, S. Kang, B.S. McEwen, M.Stein, Adrenal steroid receptor activation in rat brain and pituitary following dexamethasone: implications for the dexamethasone suppression test, Biol. Psychiatry., 32 , 850-869 (1992).

21) S.M. Grunberg, P.J. Hesketh, Control of chemotherapyinduced emesis, N. Engl. J. Med., 24 , 1790-1796 (1993).

22) K. Hosomi, Y. Kubo, A. Okuno, Y. Umetani, M. Hashimoto, T. A raya, H. Komori, M. Hirai, K. Matsuyama, Clinical Efficacy of Shitei-decoction for Hiccups. J. Pharm. Health Care Sci., 31 , 228-232 (2005). 